\title{
Predicting Gene Interactions in Tumor Microenvironment using Patient Derived Spheroid Primary Cell Culture
}

Murdani Abdullah ( $\sim$ kolitgastro@gmail.com)

University of Indonesia: Universitas Indonesia https://orcid.org/0000-0003-4565-1520

Amanda Pitarini Utari

University of Indonesia: Universitas Indonesia

Saskia Aziza Nursyirwan

University of Indonesia: Universitas Indonesia

Dimas Ramadhian Noor

University of Indonesia: Universitas Indonesia

Research note

Keywords: Colorectal cancer, Tumor Microenvironment, Primary Culture, Spheroid Culture, Gene Interactions

Posted Date: March 31st, 2021

DOI: https://doi.org/10.21203/rs.3.rs-362849/v1

License: (c) (i) This work is licensed under a Creative Commons Attribution 4.0 International License. Read Full License 


\section{Abstract \\ Objective}

Cancer is a heterogenic disease from genetic to individual levels, which induced a variety of therapheutical research and disease progression. Cancer heterogeneity were also observed in most of solid tumors including colorectal cancer. Tumor growth depends on intra-tumoral complexity in which tumor cells surrounded by several cells in their nische known as tumor microenvironment. In this study, we are using spheroid derived primary culture derived from patients to predict expression pattern of tumor growth in their microenvironment in vitro. The gene list were data which obtained from our other "on going publications"

\section{Results}

In this study, we cultured patient-derived primary cells for 7 days and analyzed 24 genes that positively expressed in this in vitro system. Using STRING, we presented interactions between proteins which later may predict the interaction between the cells. The result shown that the cells actively using carbon metabolism to maintain energy, to produce several protection mechanism against oxidative stress to evade apoptosis, and to stimulate several protein related to epithelial to mesenchymal transition and angiogenesis in vitro.

\section{Introduction}

Colorectal cancer (CRC) is a malignancy in large intestine tissue, consisting of the colon and/or rectum. (1) Colorectal cancer is the third leading cause of all new cancer cases and is the leading cause of cancer-related death worldwide.(2) Apart from the high mortality rate, CRC is also causing problems due to the incidence of relapse and drug resistance. $(3,4)$ Tumor growth may be influenced by multi factorial factors such as mutations inside the tumor, expression pattern and also influenced by its environment.(5, $6,7)$ The tumors were interacting with other cells inside the nische including tumor associated fibroblast, tumor associated immunity or Tumor Associated Macrophages (TAM), tumor associated netrophils, endothelial cells and T cells which together contributed to tumor progressions.(8-17) This complex mechanism also influenced tumor sensitivity towards distinct treatments such as radiotheraphy and chemotherapheutical agents. $(18,19)$

Tumor microenvironment can be studied using biopsies samples to understanding celullar compositions as well as protein expression inside cell nische. (20) Such strategies were advanced for the prediction of patient survival, progression or respond to certain therapheutical options in clinical settings. $(21,22,23)$ However, biopsy does not virtually describe how the cells grow. One of the most potential tools to predict microenvironment is spheroid cultures, since the spheroid culture has more resemblance to physiological condition (24). It also supports mesenchymal stem cell in vitro, and enable to study tumor angiogenesis in vitro. $(25,26,27)$ Furthermore, 3D and spheroid cultures allow cross talk of cancer cells to endothelial 
cell and allow the study of macrophage plasticity. $(28,29)$ Therefore, our main idea was to use spheroid based primary culture derived from biopsies in order to find out what type of genes that expressed in order to predict tumor budding behaviour or growth pattern in vitro.

\section{Methods}

1. Patients and Sample Collections.

Samples were collected from patients who gave their written informed consent for inclusion before participate in the study. The study was conducted in accordance with the Declaration of Helsinki, and the protocol has been approved by the Ethical Committee of Faculty of Medicine, Universitas Indonesia. Protocol ID : 20-04-0643

\section{Tissue Extractions}

The biopsies were extracted using mechanical digestions by dicing the tissue into $3-5 \mathrm{~mm}^{3}$. Tissue then dipped into 0.1 \% of Povidine lodines in Dulbeco's Modified Eagle Medium (DMEM, Gibco, USA). The fragments were then extracted with $10 \mathrm{cc}$ syringe plug and centrifuged briefly at $300 \mathrm{xg}$ for 5 minutes in RT. The pellet were suspended with complete DMEM (Gibco, USA) supplemented with $10 \%$ of Fetal Bovine Serum (Gibco, USA) and $1 \%$ of Antibiotic-Antimycotic solutions (Gibco, USA).

\section{Spheroid Culture}

The cell suspensions were counted using trypan blue exculsion assay and 10,000 of viable cells were seeded in 96 well u-plate (Nunc-Sphera, Thermoscientific, USA). The cells were cultured in complete medium for approximately 7-9 days without changing the medium. The morphology were captured using inverted microscope of Axio Carl Zeiss using Zen blue 2.1.edition software in 5x maginifications.

\section{RNA Extractions and cDNA synthesis.}

The cells were harvested by pippeting and suspended by centrifuging at $300 \mathrm{xg}$ for 5 minutes. The RNA were extracted using RNA Miniprep plus (Zymo Research, USA) according to manufacturer's protocol. The RNA were directly reverse transcribed using RT First Strand Kit (Qiagen, Hildenburg, Germany) according to the standard protocol.

5. RT-Profiler using Cancer Pathway Finder.

The quantitative expression were performed using Human Cancer Pathway Finder (Qiagen, Hildenburg, Germany) using Sybr Green (Qiagen, Hildenburg, Germany) according to manufacturer's protocol. The PCR were done in ABI 7500 FAST and data were collected according to recommendations set up. The positivity were confirmed while amplifications reached above background signal and detected between cycle 20-39. 
6. Protein Networking Analysis.

The list of positively expressed were then analyzed using STRING and its predicted pathway were obtained.

\section{Results}

1. Establishment of Primary Spheroid culture.

Primary cultures were able to be generated at day 7. In this method, we were able to generate spheroids. Figure 1 shows heterogeneity of primary culture under in vitro conditions (10,000 cells/well). Complexity of the primary cells is shown by the morphology of epithelial cells which is the rounded cells. In our experiments, using smaller density such as 1,000 cells per well generated a more compact spheroid as shown in figure 1.

2. Detection of Positive genes using RT-PCR.

The genes positively expressed were detected using PCR at cycle 20-40. The list of genes and its CT were shown in figure 2 while most of the genes were expressed between CT 35 and 40.

\section{Protein Networking Analysis.}

The gene list were analyzed using STRING and several interactions were found as shown in figure 3 . Two genes with no interactions were ACSL4 and CCND3.

\section{Discussion}

The protein network shown in figure 3 indicates at least several pathways have correlations. We first describes the metabolism in cancer. Gene expressions playing role in metabolisms were G6PD, PFKL and LDHA which mostly found in carbon metabolism.(31) Other proteins were HRPT1, while protein ACSL4 were not connected to any networking. PFKL known as phosphofructokinase is a rate limiting enzyme in glycolisis which supports glucose metabolism. It has strong connection with LDHA protein in anaerobic metabolism known as warburg effect to maintain tumor proliferations. $(32,33)$ Warburg effect produces energy for the cells to maintain the cell growth and and its fast proprety makes it commonly used by tumor cells.(34) This effect also related with hypoxia pathway, which may occured inside the core of spheroid that mimics tumor property. $(35,36)$

Beside its role in glucose metabolism, PFKL and G6PD expressions revealed deeper knowledge on cancer metabolism. G6PD or Glucose-6-phosphate Dehydrogenase is a rate limiting enzymes of pentose phosphate pathway. It is a pathway that supports ribose-5-phosphate synthesis required to sintesize nucleotide.(31) Another important finding is the connection with HPRT1, a gene responsible in de salvage pathway to provide nucleotides.(37) Therefore, the tumor may activate pathway that produce 5-ribose phosphate for nucleotide backbone and actively reproduce de salvage by expressing HRPT1. The 
importance of G6PD is its role to provide NADPH for power reducer. It is neccesary to regenerate fatty acid. Inside the networking there were no connections or any other informations related to fatty acid synthesis. However, ACSL4 which is known to ligate long fatty acid to coenzyme A and to synthesize long fatty acid, is essential in metabolism, modification of membranes structures, and proliferation.(38) Together with G6PD expression, we assumed that NADPH was also used by cells for the synthesis of fatty acid.

Interestingly, SOD1 known as cytosolic superoxides were also expressed. this may indicate that the tumors protect its cells from reactive superoxide generated as metabolism byproduct by expressing the SOD1. The SOD1 has a protective property against anion superoxide produced by several metabolic pathway.(39) Taken together with G6PD expression, the tumor cells may provide higher reducing power such as NADPH protein expression and high ROS productions inside the cells to support the tumor growth.

The network analysis conveyed positive expression of CASP7, CFLAR and XIAP. CASP7 overexpression were known to induced apoptosis. $(40,41)$ However, in cancer cells overexpression of CASP7 usually indicates poor prognostic factos. Other protein expressed was CLFAR, known as programmed cell death. It modulates apoptotic pathway by regulating caspase-8 activations. (42) Lastly, XIAP protein, also knowns as modulator. This protein regulates apoptosis by directly bind to binding pocket of caspase-7 and caspase-3. $(43,44)$ The proteins were known to inhibits proteasomal degradations that promotes autophagy(45).

To support cell growth, the cells are mostly maintaining complex mechanisms. One of the main mechanism is angiogenesis. TEK, ANGPT1, VEGFC and FLT1 conveyed that the cells support angiogenesis related pathways. TEK, also known as Tie2, were expressed on tumors vasculature. While ANGPT1 overexpression is related to the increasing tumorigenicy of breast cancer cell lines. (46) TEK and ANGPT1 expression may indicate that spheroids may describe tumors and endothelial crosstalk communications. VEGFC overexpression is known to correlate with poorer survival as it supports tumor growth.(47) Moreover, FLT1 is known to support not only tumor growth but also metastasis and mostly due to its interactions with macrophages.(48) Interestingly, SERPINF1 expression, known as antiangiogenic factors, may be released by certain cells inside this spheroid cultures to suppress the tumor growth.(49) This is interesting, since suppresion of this SERPINF1 could induce tumor promoting phenotype of cancer associated fibroblast.(50)

We also found interactions of FOXC2 and CDH2. FOXC2 may be related to TEK and angiogenesis since FOXC2 supports angiogenesis and disease progression (51). Its connection with $\mathrm{CDH} 2$ may be related to reprogramming event of epithelial to mesenchymal transitions (EMT), indicating celullar plasticity.(52) $\mathrm{CDH} 2$ were related to aggresive phenotypes and protections of microenvironment against therapheutical agent.(53) Moreover, the expression of SNAI3 and KRT14 related to $\mathrm{CDH} 2$, may indicate EMT process inside the spheroids.(54) Despite its interactions were closely related to apoptosis, PINX-1 and TINF2 
expression may be related to tumor suppresion effect inside the spheroids.(55) Therefore, at certain extend some cells may have tried to suppress the tumor growth.

However, the expression of IGFB3 and CCND3 were found. IGFB3 may be related to hypoxia related signaling, induced by hypoxic microenvironment.(56) Serum IGFBP3 is known to correlate with VEGFC and may be related to metastasis insidence.(57) IGFB3 were also shown to bind with several growth factors.(58) Lastly, CCND3 expression may be related to malignancy and tumor growth capacity, since its known as poor overall survival prognostic.(58)

\section{Limitations}

- The spheroid culture were able to be conducted, through using one patients as representative data. To gain more information, at least two or three patients should be analyzed using the same assay.

- Genes interactions may not representate the true metabolism, therefore metabolited should be at least measured in the future.

- The multiple cell staining were not conducted, therefore genes and cell interactions were only limited to genes interactions.

\section{Abbreviations}


ACSL4 Acyl-CoA Synthetase Long Chain Family Member 4

\begin{tabular}{|c|c|}
\hline ANGPTI1 & Angiopoietin 1 \\
\hline CASP7 & Caspase-7 \\
\hline CCND3 & Cyclin D3 \\
\hline $\mathrm{CDH} 2$ & Cadherin 2 \\
\hline CFLAR & CASP8 And FADD Like Apoptosis Regulator \\
\hline CRC & Colorectal Cancer \\
\hline CT & Cycle Threshold \\
\hline DMEM & Dulbecco's Modified Eagle Medium \\
\hline EMT & Epithelial-Mesenchymal Transition \\
\hline FLT1 & Fms-related tyrosine kinase 1 \\
\hline FOXC2 & Forkhead Box C2 \\
\hline G6PD & Glucose-6-Phosphate Dehydrogenase \\
\hline HRPT1 & Hypoxanthine Phosphoribosyltransferase 1 \\
\hline IGFB3 & Insulin-like growth factor-binding protein 3 \\
\hline KRT14 & Keratin-14 \\
\hline LDHA & Lactate Dehydrogenase A \\
\hline PFKL & phosphofructokinase, liver type \\
\hline PINX-1 & IN2/TERF1-interacting telomerase inhibitor 1 \\
\hline RT-PCR & reverse-transcriptase polymerase chain reaction \\
\hline SERPINF1 & Serpin Family F Member 1 \\
\hline SNAI3 & Snail Family Transcriptional Repressor 3 \\
\hline SOD1 & Superoxide Dismutase 1 \\
\hline TAM & Tumor Associated Macrophage \\
\hline TEK & TEK Receptor Tyrosine Kinase \\
\hline TINF2 & TERF1 Interacting Nuclear Factor 2 \\
\hline VEGFC & Vascular Endothelial Growth Factor C \\
\hline XIAP & X-linked inhibitor of apoptosis protein \\
\hline
\end{tabular}




\section{Declarations}

\section{Ethics Approval and Consent to Participate}

This is a study involving human tissue with ethical approval granted by Ethical committee from University of Indonesia, Protocol ID : 20-04-0643.

\section{Availability of the Data Sets and Material.}

The datasets of gene lists and figure already listed within this manuscript. STRING analysis of those list can be analyzed using the online tools.

\section{Funding}

HIBAH PUTI Q2 Universitas Indonesia 2020 funds the research.

\section{Acknowlegement}

We acknowledge Asiyah Nurul Fadila and Nadhira Nizam for drafting and submitting the manuscript.

\section{Consent For Publication.}

Non Applicable.

\section{Competing Interest.}

The authors declare that they have no competing interest.

\section{Author's Contribution}

MA, APU and SAN concept and design the work. SAN and DRN acquire and analyse the data. MA and DRN interpret the data. All authors have read and approved the final manuscript.

\section{References}

1. Kuipers EJ, Grady WM, Lieberman D, Seufferlein T, Sung JJ, Boelens PG, et al. Colorectal cancer. Nat Rev Dis Primer. 2015 Nov 5;1:15065-15065.

2. Bray F, Ferlay J, Soerjomataram I, Siegel RL, Torre LA, Jemal A. Global cancer statistics 2018 : GLOBOCAN estimates of incidence and mortality worldwide for 36 cancers in 185 countries. CA 
Cancer J Clin. 2018 Nov 1;68(6):394-424.

3. Van der Jeught K, Xu H-C, Li Y-J, Lu X-B, Ji G. Drug resistance and new therapies in colorectal cancer. World J Gastroenterol. 2018 Sep 14;24(34):3834-48.

4. Rawla P, Sunkara T, Barsouk A. Epidemiology of colorectal cancer: incidence, mortality, survival, and risk factors. Przeglad Gastroenterol. 2019/01/06 ed. 2019;14(2):89-103.

5. Anandakrishnan R, Varghese RT, Kinney NA, Garner HR. Estimating the number of genetic mutations (hits) required for carcinogenesis based on the distribution of somatic mutations. PLOS Comput Biol. 2019 Mar 7;15(3):e1006881.

6. Hernandez A, Smith F, Wang Q, Wang X, Evers BM. Assessment of differential gene expression patterns in human colon cancers. Ann Surg. 2000 Oct;232(4):576-85.

7. Whiteside TL. The tumor microenvironment and its role in promoting tumor growth. Oncogene. 2008 Oct 6;27(45):5904-12.

8. Liu T, Zhou L, Li D, Andl T, Zhang Y. Cancer-Associated Fibroblasts Build and Secure the Tumor Microenvironment. Front Cell Dev Biol. 2019 Apr 24;7:60-60.

9. Chen Y, Song Y, Du W, Gong L, Chang H, Zou Z. Tumor-associated macrophages: an accomplice in solid tumor progression. J Biomed Sci. 2019 Oct 20;26(1):78.

10. Pan Y, Yu Y, Wang X, Zhang T. Tumor-Associated Macrophages in Tumor Immunity. Front Immunol. 2020 Dec 3;11:583084-583084.

11. Masucci MT, Minopoli M, Carriero MV. Tumor Associated Neutrophils. Their Role in Tumorigenesis, Metastasis, Prognosis and Therapy. Front Oncol. 2019 Nov 15;9:1146-1146.

12. Shaul ME, Fridlender ZG. Tumour-associated neutrophils in patients with cancer. Nat Rev Clin Oncol. 2019 Oct 1;16(10):601-20.

13. Chouaib S, Kieda C, Benlalam H, Noman MZ, Mami-Chouaib F, Rüegg C. Endothelial cells as key determinants of the tumor microenvironment: interaction with tumor cells, extracellular matrix and immune killer cells. Crit Rev Immunol. 2010;30(6):529-45.

14. Nagl L, Horvath L, Pircher A, Wolf D. Tumor Endothelial Cells (TECs) as Potential Immune Directors of the Tumor Microenvironment - New Findings and Future Perspectives. Front Cell Dev Biol. 2020;8:766.

15. Sobierajska K, Ciszewski WM, Sacewicz-Hofman I, Niewiarowska J. Endothelial Cells in the Tumor Microenvironment. Adv Exp Med Biol. 2020;1234:71-86.

16. Ostroumov D, Fekete-Drimusz N, Saborowski M, Kühnel F, Woller N. CD4 and CD8 T lymphocyte interplay in controlling tumor growth. Cell Mol Life Sci CMLS. 2017/10/14 ed. 2018 Feb;75(4):689713.

17. Riazi Rad F, Ajdary S, Omranipour R, Alimohammadian MH, Hassan ZM. Comparative analysis of CD4+ and CD8+ T cells in tumor tissues, lymph nodes and the peripheral blood from patients with breast cancer. Iran Biomed J. 2015;19(1):35-44. 
18. van den Ende T, van den Boorn HG, Hoonhout NM, van Etten-Jamaludin FS, Meijer SL, Derks S, et al. Priming the tumor immune microenvironment with chemo(radio)therapy: A systematic review across tumor types. Biochim Biophys Acta BBA - Rev Cancer. 2020 Aug 1;1874(1):188386.

19. Kershaw M, Devaud C, John L, Westwood J, Darcy P. Enhancing immunotherapy using chemotherapy and radiation to modify the tumor microenvironment. Oncoimmunology. 2013 Sep 1;2:e25962.

20. Lara OD, Krishnan S, Wang Z, Corvigno S, Zhong Y, Lyons Y, et al. Tumor core biopsies adequately represent immune microenvironment of high-grade serous carcinoma. Sci Rep. 2019 Nov 26;9(1):17589.

21. Yuan JX, Bafakih FF, Mandell JW, Horton BJ, Munson JM. Quantitative Analysis of the Cellular Microenvironment of Glioblastoma to Develop Predictive Statistical Models of Overall Survival. J Neuropathol Exp Neurol. 2016 Dec 1;75(12):1110-23.

22. Park J, Wyk HC, Mcmillan D, Edwards J, Orange C, Horgan P, et al. Pre-operative, biopsy-based assessment of the tumour microenvironment in patients with primary operable colorectal cancer. $\mathrm{J}$ Pathol Clin Res. 2019 Sep 4;6.

23. Baghban R, Roshangar L, Jahanban-Esfahlan R, Seidi K, Ebrahimi-Kalan A, Jaymand M, et al. Tumor microenvironment complexity and therapeutic implications at a glance. Cell Commun Signal. 2020 Apr 7;18(1):59.

24. Duval K, Grover H, Han L-H, Mou Y, Pegoraro AF, Fredberg J, et al. Modeling Physiological Events in 2D vs. 3D Cell Culture. Physiology. 2017 Jun 14;32(4):266-77.

25. Cesarz Z, Tamama K. Spheroid Culture of Mesenchymal Stem Cells. Li R-K, editor. Stem Cells Int. 2015 Nov 16;2016:9176357.

26. Amann A, Zwierzina M, Koeck S, Gamerith G, Pechriggl E, Huber JM, et al. Development of a 3D angiogenesis model to study tumour - endothelial cell interactions and the effects of antiangiogenic drugs. Sci Rep. 2017 Jun 7;7(1):2963.

27. Pfisterer L, Korff T. Spheroid-Based In Vitro Angiogenesis Model. Methods Mol Biol Clifton NJ. 2016;1430:167-77.

28. Shoval H, Karsch-Bluman A, Brill-Karniely Y, Stern T, Zamir G, Hubert A, et al. Tumor cells and their crosstalk with endothelial cells in 3D spheroids. Sci Rep. 2017 Sep 5;7(1):10428.

29. Rebelo SP, Pinto C, Martins TR, Harrer N, Estrada MF, Loza-Alvarez P, et al. 3D-3-culture: A tool to unveil macrophage plasticity in the tumour microenvironment. Biomaterials. 2018 May 1;163:18597.

30. Jensen LJ, Kuhn M, Stark M, Chaffron S, Creevey C, Muller J, et al. STRING 8-a global view on proteins and their functional interactions in 630 organisms. Nucleic Acids Res. 2009 Jan;37(Database issue):D412-416.

31. Cho ES, Cha YH, Kim HS, Kim NH, Yook JI. The Pentose Phosphate Pathway as a Potential Target for Cancer Therapy. Biomol Ther. 2018 Jan 1;26(1):29-38.

32. Li X-B, Gu J-D, Zhou Q-H. Review of aerobic glycolysis and its key enzymes - new targets for lung cancer therapy. Thorac Cancer. 2015/01/07 ed. 2015 Jan;6(1):17-24. 
33. Vander Heiden MG, Cantley LC, Thompson CB. Understanding the Warburg effect: the metabolic requirements of cell proliferation. Science. 2009 May 22;324(5930):1029-33.

34. Fadaka A, Ajiboye B, Ojo O, Adewale O, Olayide I, Emuowhochere R. Biology of glucose metabolization in cancer cells. J Oncol Sci. 2017 Jul 1;3(2):45-51.

35. Cui X-G, Han Z-T, He S-H, Wu X, Chen T-R, Shao C-H, et al. HIF1/2a mediates hypoxia-induced LDHA expression in human pancreatic cancer cells. Oncotarget. 2017 Apr 11;8(15):24840-52.

36. Riffle S, Hegde RS. Modeling tumor cell adaptations to hypoxia in multicellular tumor spheroids. J Exp Clin Cancer Res CR. 2017 Aug 3;36(1):102-102.

37. Nyhan W. Nucleotide Synthesis via Salvage Pathway. In: eLS. 2005.

38. Yan S, Yang X-F, Liu H-L, Fu N, Ouyang Y, Qing K. Long-chain acyl-CoA synthetase in fatty acid metabolism involved in liver and other diseases: An update. World J Gastroenterol WJG. 2015 Mar 28;21:3492-8.

39. Che M, Wang R, Li X, Wang H-Y, Zheng XFS. Expanding roles of superoxide dismutases in cell regulation and cancer. Drug Discov Today. 2015/10/19 ed. 2016 Jan;21(1):143-9.

40. Chaudhary S, Madhukrishna B, Adhya AK, Keshari S, Mishra SK. Overexpression of caspase 7 is ERa dependent to affect proliferation and cell growth in breast cancer cells by targeting p21(Cip). Oncogenesis. 2016 Apr 18;5(4):e219-e219.

41. Lamkanfi M, Kanneganti T-D. Caspase-7: A protease involved in apoptosis and inflammation. Int J Biochem Cell Biol. 2009 Sep 1;42:21-4.

42. Wang P-X, Ji Y-X, Zhang X-J, Zhao L-P, Yan Z-Z, Zhang P, et al. Targeting CASP8 and FADD-like apoptosis regulator ameliorates nonalcoholic steatohepatitis in mice and nonhuman primates. Nat Med. 2017 Apr;23(4):439-49.

43. Shi Y. Mechanisms of Caspase Activation and Inhibition during Apoptosis. Mol Cell. 2002 Mar 1;9(3):459-70.

44. Chaudhary AK, Yadav N, Bhat TA, O'Malley J, Kumar S, Chandra D. A potential role of X-linked inhibitor of apoptosis protein in mitochondrial membrane permeabilization and its implication in cancer therapy. Drug Discov Today. 2015/07/30 ed. 2016 Jan;21(1):38-47.

45. Huang X, Wu Z, Mei Y, Wu M. XIAP inhibits autophagy via XIAP-Mdm2-p53 signalling. EMBO J. 2013/06/07 ed. 2013 Aug 14;32(16):2204-16.

46. Hayes AJ, Huang WQ, Yu J, Maisonpierre PC, Liu A, Kern FG, et al. Expression and function of angiopoietin-1 in breast cancer. Br J Cancer. 2000 Nov;83(9):1154-60.

47. Chen J-C, Chang Y-W, Hong C-C, Yu Y-H, Su J-L. The role of the VEGF-C/VEGFRs axis in tumor progression and therapy. Int J Mol Sci. 2012 Dec 20;14(1):88-107.

48. Shibuya M. Involvement of Flt-1 (VEGF receptor-1) in cancer and preeclampsia. Proc Jpn Acad Ser B Phys Biol Sci. 2011;87(4):167-78.

49. Belkacemi L, Zhang SX. Anti-tumor effects of pigment epithelium-derived factor (PEDF): implication for cancer therapy. A mini-review. J Exp Clin Cancer Res. 2016 Jan 8;35(1):4. 
50. Nwani NG, Deguiz ML, Jimenez B, Vinokour E, Dubrovskyi O, Ugolkov A, et al. Melanoma Cells Block PEDF Production in Fibroblasts to Induce the Tumor-Promoting Phenotype of Cancer-Associated Fibroblasts. Cancer Res. 2016 Apr 15;76(8):2265-76.

51. Kume T. The Role of FoxC2 Transcription Factor in Tumor Angiogenesis. Mukhopadhyay D, editor. J Oncol. 2011 Nov 16;2012:204593.

52. Drasin DJ, Robin TP, Ford HL. Breast cancer epithelial-to-mesenchymal transition: examining the functional consequences of plasticity. Breast Cancer Res. 2011 Nov 1;13(6):226.

53. Mrozik KM, Blaschuk OW, Cheong CM, Zannettino ACW, Vandyke K. N-cadherin in cancer metastasis, its emerging role in haematological malignancies and potential as a therapeutic target in cancer. BMC Cancer. 2018 Oct 1;18(1):939-939.

54. Martinelli P, Carrillo-de Santa Pau E, Cox T, Sainz B, Dusetti N, Greenhalf W, et al. GATA6 regulates EMT and tumour dissemination, and is a marker of response to adjuvant chemotherapy in pancreatic cancer. Gut. 2017 Sep 1;66(9):1665.

55. Shi M, Cao M, Song J, Liu Q, Li H, Meng F, et al. PinX1 inhibits the invasion and metastasis of human breast cancer via suppressing NF-KB/MMP-9 signaling pathway. Mol Cancer. 2015 Mar 26;14.

56. Natsuizaka M, Naganuma S, Kagawa S, Ohashi S, Ahmadi A, Subramanian H, et al. Hypoxia induces IGFBP3 in esophageal squamous cancer cells through HIF-1a-mediated mRNA transcription and continuous protein synthesis. FASEB J Off Publ Fed Am Soc Exp Biol. 2012/03/13 ed. 2012 Jun;26(6):2620-30.

57. Morgillo F, De Vita F, Antoniol G, Orditura M, Auriemma PP, Diadema MR, et al. Serum insulin-like growth factor 1 correlates with the risk of nodal metastasis in endocrine-positive breast cancer. Curr Oncol Tor Ont. 2013 Aug;20(4):e283-8.

58. Wang EA, Chen W-Y, Wong C-H. Multiple Growth Factor Targeting by Engineered Insulin-like Growth Factor Binding Protein-3 Augments EGF Receptor Tyrosine Kinase Inhibitor Efficacy. Sci Rep. 2020 Feb 17;10(1):2735.

59. Ding Z-Y, Li R, Zhang Q-J, Wang Y, Jiang Y, Meng Q-Y, et al. Prognostic role of cyclin D2/D3 in multiple human malignant neoplasms: A systematic review and meta-analysis. Cancer Med. 2019 Jun;8(6):2717-29.

\section{Figures}




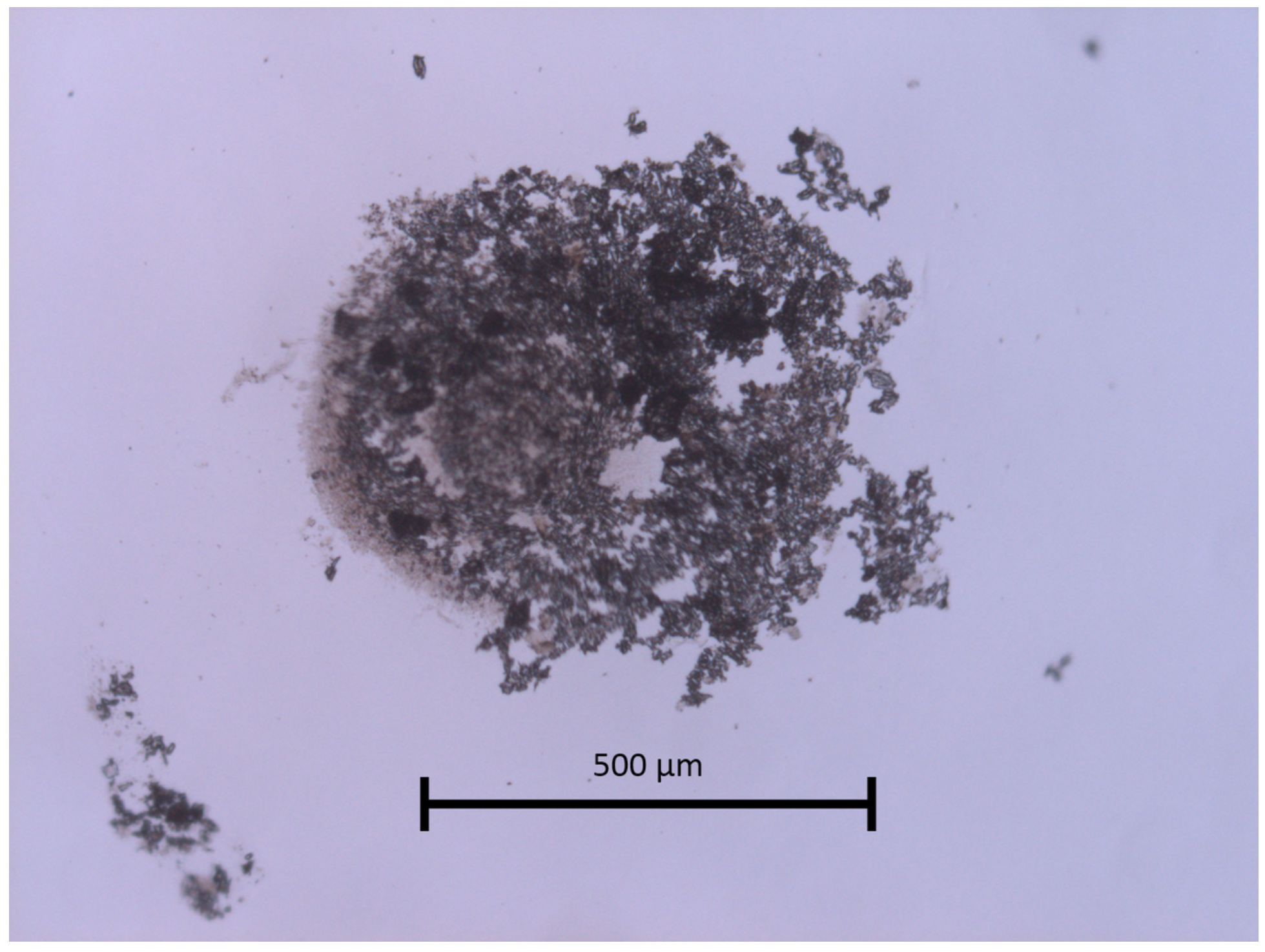

Figure 1

Spheroid at day 7 of culture with 1,000 cells per well. 


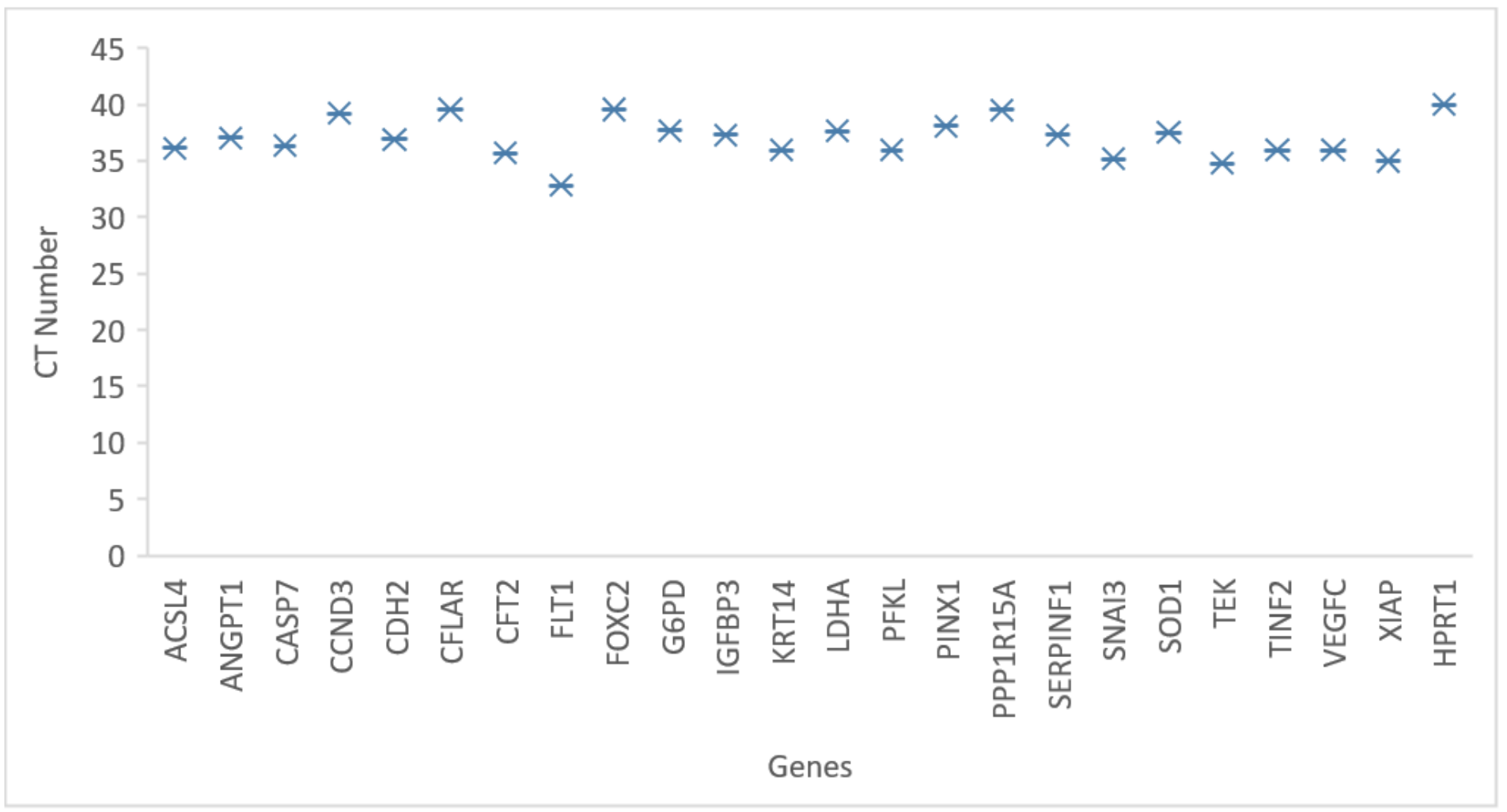

\section{Figure 2}

Genes expression detected in Human Cancer Pathway Finder. The results showed 24 positive genes in this spheroid culture. 


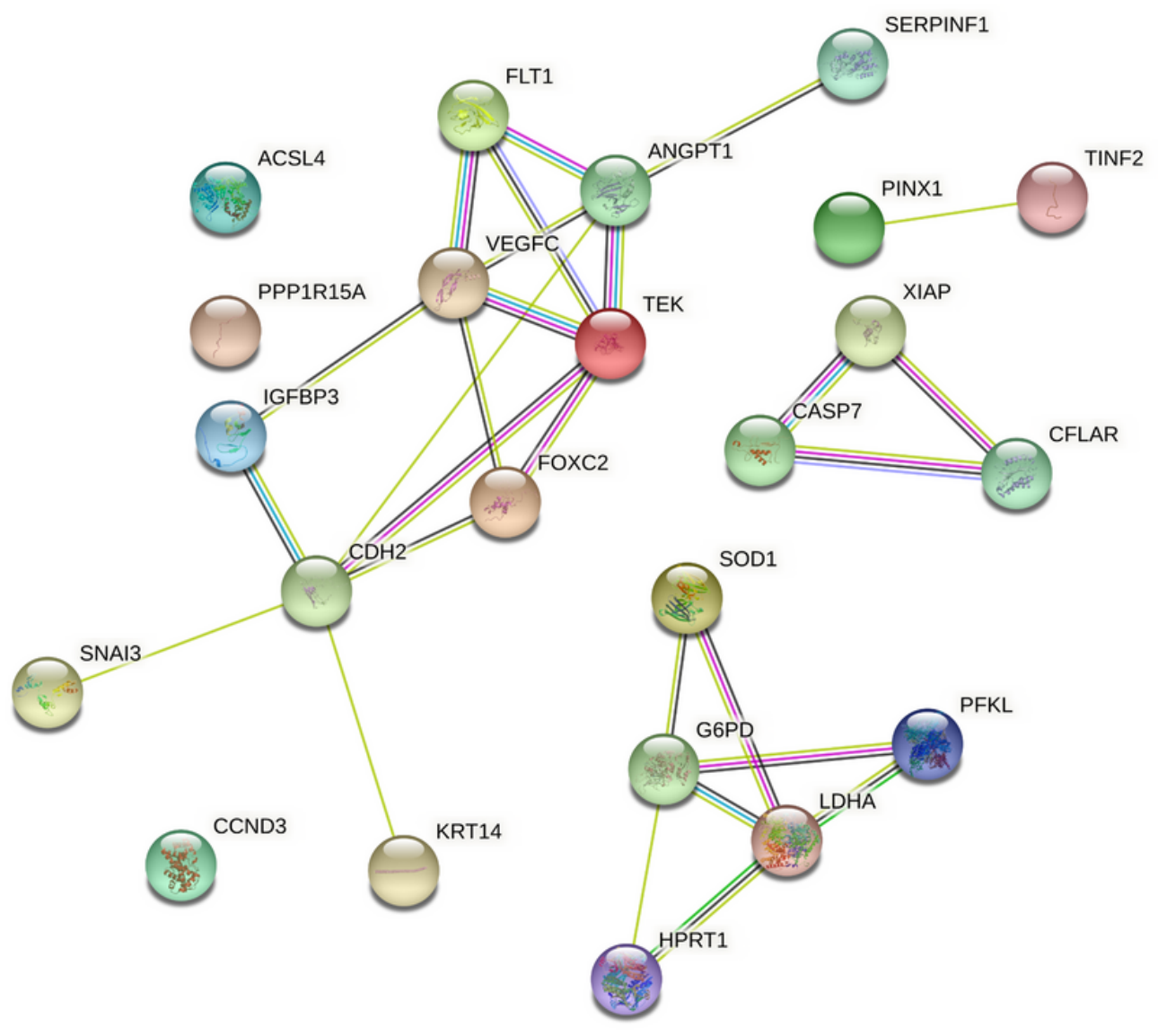

Figure 3

Protein interaction prediction of 24 expressed genes using STRING. The networking conveys proteins playing role in common metabolism, apoptosis, cancer related metabolism.(30)

\section{Supplementary Files}

This is a list of supplementary files associated with this preprint. Click to download.

- SUPPLEMENTARYFIGURES.docX 